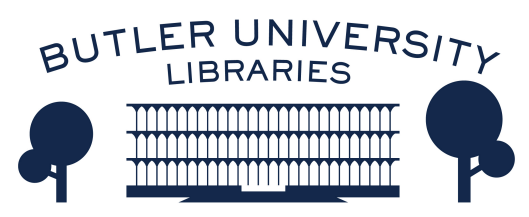

Journal of Hindu-Christian Studies

Volume 13

Article 6

January 2000

\title{
Reverend William Ward and His Legacy for Christian (Mis)perception of Hinduism
}

Brian K. Pennington

Follow this and additional works at: https://digitalcommons.butler.edu/jhcs

Part of the Religion Commons

\section{Recommended Citation}

Pennington, Brian K. (2000) "Reverend William Ward and His Legacy for Christian (Mis)perception of Hinduism," Journal of Hindu-Christian Studies: Vol. 13, Article 6.

Available at: https://doi.org/10.7825/2164-6279.1226

The Journal of Hindu-Christian Studies is a publication of the Society for Hindu-Christian Studies. The digital version is made available by Digital Commons @ Butler University. For questions about the Journal or the Society, please contact cbauman@butler.edu. For more information about Digital Commons @ Butler University, please contact digitalscholarship@butler.edu. 


\title{
Reverend William Ward and His Legacy for Christian (Mis)perception of Hinduism
}

\author{
Brian K. Pennington \\ Maryville College
}

\begin{abstract}
MY ASSIGNMENT FOR this thematic issue of the Hindu-Christian Studies Bulletin is to address Christian misperceptions of Hinduism, which I shall do by evaluating the work and legacy of William Ward of Serampore, missionary to Bengal, and author on Hinduism in the early nineteenth century. First, however, I would like to make three preliminary observations about the idea of "Christian misperception".
\end{abstract}

\section{"Christians" and Their "Mispercep- tions"}

The first observation concerns "perception" itself. Prominent intellectual traditions in both India and the West have maintained that all perception is, at base, misperception. To cite the most notable examples, German philosopher Immanuel Kant insisted that data are available to consciousness only as the result of having been organized by the categories of human understanding, which thereby obstruct the access of consciousness to the "thing in itself". Similarly, Vedanta exponent Samkara taught that the true nature of reality is veiled by maya (illusion), under whose power all human perception labours. More recently, much critical theory and historiography - postcolonial theory, for example - has turned on the principle that all knowledges are products of the historical and social location of the knower. These insights suggest that any evaluation of interreligious contact recognize that mutual, provisional misperception is an important first step in these encounters.

Second, consideration of this topic must take note of the relationship between perception and representation. Perception of the "Other" is as inseparable an aspect of cross-cultural encounter " as sensory perception is of human interaction with the natural and social worlds generally. In interreligious encounter, perception of the Other is problematic because it usually takes shape in the context of the perceiver's commitment to a rival religious worldview. It acquires, however, an especially problematic character when it passes over into representation; when, that is, one set of fragmentary or inadequately conceptualized apprehensions reproduces itself in the minds of others. Misrepresentation then becomes the source of another's misperception. If Christians routinely misperceive Hinduism (and I believe they do), it is helpful to recall that at the root of such misapprehension is often a pattern of prior misrepresentation.

Third, responsibly addressing this topic demands a complexification of the label "Christian". To speak of "Christian" perceptions of Hinduism is, of course, flagrantly over-general. The failure of both Hindus and Christians to appreciate the complexity, variety, and internal divisions of each other's traditions remains a cardinal source of their mutual misunderstanding. For the sake of the topic at hand, it may be useful to distinguish among three types of Christian perceptions of Hinduism, each conditioned by its prior commitments to a distinctive Christianity and by a distinctive encounter with Hinduism. The insulated perceptions of Christians who have had little contact with Hinduism implicitly accept the sufficiency and universality of Christian categories for apprehending Hindu phenomena. Such Christians lack both the ability and desire to 
comprehend Hinduism according to its own categories of representation. Evangelizing perceptions apprehend Hinduism under the influence of a prior commitment to undermining the attachment of Hindus to their religion. They may often take shape in Christians well-informed about Hinduism, who explicitly reject, however, the categories of Hindu self-representation. Pluralist perceptions are characterized by an attempt to suspend the operation of received Christian categories and to apprehend Hinduism on its own terms in order to appreciate its character or to promote harmonious relations between Hindus and Christians. Each of these three possibilities represents a common Christian approach to Hinduism, but to Hindus, often only evangelizing perceptions have been widely manifest as representation and have thereby become the source of interreligious tension, rivalry, and violence.

\section{Missionary Ethnographer}

These observations are important for contextualizing the work of William Ward, who represents the evangelizing Christian encounter with Hinduism and was, by many accounts, one of the most egregious misperceivers of Hinduism in the modern age. ${ }^{1}$ The influence of Ward, missionary and printer at the British Baptist mission at Serampore, spread throughout the Englishspeaking world in the early nineteenth century, largely on the basis of his massive 1806-11 study of Hindu thought and ritual, originally entitled, Account of the Writings, Religion, and Manners of the Hindoos: Including Translations from Their Principal Works. ${ }^{2}$ Ward regularly revised and reissued his study as he became more competent in Bengali and Sanskrit and more widely read in Hindu literature. The text went through three more editions in nine years, each bearing some variant of the title $A$ View of the History, Literature, and Mythology of the Hindoos. ${ }^{3}$

A carpenter's son, William Ward was born in 1769 in Derby, England. He spent his youth as a printer's apprentice, and later worked variously as editor and publisher of newspapers in Derby, Stafford, and Hull. His espousal of republican politics and support for the French Revolution led twice to his arrest under Pitt. At the age of twentysix, Ward experienced conversion. A thirst for justice and compassion for the poor remained his primary vocational motivations, but the field of his action changed. He abandoned journalism and took up the evangelization of India as his life's task, sailing for Calcutta in 1799 with three other colleagues and their wives to meet Baptist missionary William Carey and operate the printing press for the mission station that would become the most famous and influential in the British colonies. As part of the "Serampore Trio" that included Carey and Joshua Marshman, he achieved much success and renown among Englishspeaking Christians. When Ward died of cholera in 1823 , his colleagues would mourn the "almost irreparable loss" suffered by the cause of evangelizing Hindus. ${ }^{4}$

Ward is today remembered chiefly for his pioneering work in printing in colonial Bengal, which included supervising the production of the first typefaces for many Asian languages. ${ }^{5}$ For decades, his was "the most important printing and publishing house in the world for books in the Oriental languages". 6 In his day, he was also known for his View of the Hindoos, among the first English-language attempts at a comprehensive descriptive study of Hinduism. It had its primary and most direct influence on denominational Christianity in Britain and India; where it immediately became the standard work on Hindu religion for those interested in the spread of missions or in the missionary vocation itself. It offered a hybrid of academic description and evangelical invective against "heathen" religion, ultimately deciding that Hindu religion comprised "the most puerile, impure, and bloody, of any system of idolatry that was ever established on earth". Denominational and missionary publications freely reproduced his representations of Hindus and Hinduism, as the inflammatory nature of his narration and his graphic description of alleged Hindu abominations 
underscored the urgent responsibility of Christians to evangelize Britain's colonial possessions. Ward achieved great celebrity in England and America when, in 1819, he became the first missionary to return from the East to the English-speaking world. Before sailing back to Bengal, he spent two years lecturing to Christian audiences about Hinduism and the need for a concerted evangelical effort to subvert what he described as its sanguinary and stultifying effect on India.

The influence of his work, however, was not limited to evangelical Christian audiences. In American literature, the Transcendentalist movement led by Emerson and Thoreau formed its romantic notions about the spiritual East partly on the basis of Hindoos' translations representing the six Hindu darsanas (schools of philosophical thought). ${ }^{8}$ James Mill's influential The History of British India (1817) reflected the darker side of Ward's work, relying on Ward's study for evidence of the "folly" and "immorality" of Hinduism. Mill's deeply unsympathetic account of Indian history, polity, and religion attained currency among Parliamentarians and officials responsible for the oversight of the East India Company. ${ }^{9}$ It contributed to the decline of classical Indology and the rise of a reformist impulse in the British administration of India. Governor-General William Bentinck's abolition of sati (the immolation of a widow on her husband's funeral pyre) in 1829 and Thomas Babington Macaulay's 1835 "Minute on Education", which maligned Indian literature and learning, were symptomatic of the new mood whose genesis we can trace directly to the publication of Ward's study.

Ward's perceptions of Hinduism displayed three occupations that point to his unyielding Christian framework for ordering Hindu phenomena. First, Ward apprehended a great variety of Hindu practice under the rubric "sacrifice", including sati, the immersion of the dying in the Ganges River, puja, and isolated instances of religious murder. ${ }^{10}$ Ward applied this category widely to demonstrate Hinduism's rejection of the
Protestant doctrine that the last efficacious sacrifice was the crucifixion of Jesus Christ in atonement for the sins of all humankind. Second, to suggest Hinduism's antagonism to Christian monotheism, Ward deployed the Judeo-Christian concept of "idolatry". In a chapter entitled "Of God", Ward invoked "idolatry" to communicate Hindu ideas about deity, implying to Christian audiences two related blasphemies - a multiplication of the godhead and the worship of material form. ${ }^{11}$ Finally, in several passages, Ward noted with outrage, but without full description, instances of Hindu eroticism, which he contrasted with the modesty and decency Christianity taught with regard to sexuality. ${ }^{12}$ Drawing on the three characteristics he had imputed to Hinduism sacrifice, idolatry, and eroticism - Ward produced a concrete image of Hinduism as cruel, irrational, and licentious and concluded that "there is not a vestige of real morality in the whole of the Hindu system". ${ }^{13}$

However much Ward's evangelical agenda may have shaped the Hindoos, he produced the study initially to counter what he regarded as Indology's own misrepresentations of Hinduism. Indologists concerned with religion favoured textual sources over the study of rites in practice, seeing in popular Hinduism a decayed and compromised form of the pure religion found in its ancient texts. Shaped by his early experience in journalism, Ward was among the first authors to address this vacuum and take seriously the daily religious exercises and ejaculations of the people he knew. He regularly attended Hindu festivals and temples, and comprehended quite fully the rhythm and texture of local ritual life. His work offers glimpses into the lives of marginalized groups in early nineteenth-century Bengal, since the people with whom he was in closest and most regular contact were those of the lowest castes who stood to lose least by contact with foreign Christians. His descriptions of ceremonies surrounding birth, marriage, and death are rich with detail. To communicate the flavour of local 
culture, he also provided examples of colloquial conversation taken from the villages surrounding Serampore, including colourful exchanges such as that "Between two persons returned from the ceremony of presenting offerings to the dead". ${ }^{14}$

Blessed with keen ethnographic instincts, Ward published the Hindoos as a corrective to the European idea, kindled by translations of such works as the Bhagavad Gita and Kalidasa's Sakuntala, that the Hindu religion reflected the refined and poetic character of these texts. He complained that such translators as Sir William Jones and Nathaniel Halhed treated "The content of these [Hindu] books ... with the greatest reverence" and proclaimed that "the primitive religion of the Hindoos ... revealed the most sublime doctrines, and inculcated a pure morality". ${ }^{15}$ Ward insisted, rather, that "to know the Hindoo idolatry, as it is" a person must abandon the false impression created by an exclusive evaluation of Hindu texts, and instead he must wade through the filth of the thirty-six pooranas and other popular books - he must read and hear the modern popular poems and songs - he must follow the bramhin through his midnight orgies, before the image of Kali, and other goddesses ... or he must look at the bramhin, hurrying the trembling half dead widow round the funeral pile, and throwing her, like a log of wood, by the side of the dead body of her husband, tying her, and then holding her down with bamboo levers. ${ }^{16}$

Such passages display Ward's dual legacy: a condemnation of much of Hinduism and a truly revolutionary turn toward the everyday practices of popular religion.

\section{Anecdote as Percept}

Prior to Ward, the most widely read English publication on Hinduism was the Asiatic Society of Bengal's periodical, Asiatick Researches. First published in 1789, it counted among its contributors the great Sanskritists and Indologists of the age, Sir William Jones, H. T. Colebrooke, H. H. Wilson, and James Prinsep. With a decidedly antiquarian bent, the Researches viewed Hinduism through its ancient texts and its architectural ruins, and offered its reports in an appreciative tone. Following Ward's publication of Hindoos, however, other infamously uncharitable presentations of Hinduism appeared, including those by French priest Abbé Dubois, (Hindu Manners, Customs, and Ceremonies, 1823), Scottish missionary Alexander Duff, (India and Indian Missions, 1839), and Charles Grant, the Chairman of the Court of Directors of the East India Company, whose "Observations on the State of Society among the Asiatic Subjects of Great Britain" he had written and circulated privately in 1792 , but which Parliament published in 1813 and 1831 in the gathering hostile atmosphere. ${ }^{17}$

What characterized this new genre of description was not only the luridness but the texture of its detail. These features are characteristic of missionary reports about Hinduism, and stem from a habit of perception not characteristic of all Christian traditions. Evangelical theology inclined the missionary to consider individual experience seriously, and to observe closely the changing material and emotional fortunes of those he or she hoped eventually to convert. Missionaries' published journals, their reports to supervising missionary boards, and their letters to denominational newspapers spoke of village life, popular ceremony, and the deprivation of the impoverished. Missionaries carefully followed the lives of individuals out of both genuine biblical compassion and an eagerness for converts. The representational result was a portrait of the lower classes as victims of an exploitative and vicious religious tradition. In presenting the stories and struggles of real Hindus, moreover, this literature appealed to a popular audience and stood apart from the dry reports of East India Company bureaucrats and the elevated prose of Orientalists.

The remarks of "A Bengalee" who wrote to the Asiatic Journal in February 1821 suggest how the impressions of Ward and those Christians who followed him might rank as misperceptions. Responding to the publication in the same journal of Ward's widely-read address to the "Ladies 
of Liverpool" on the debased status of women in Hindu India, ${ }^{18}$ this correspondent protested against Ward's presentation of a flat, uniform portrait of women as descriptive of all female Hindus, and his exaggeration of the injustices women suffered. He complained that Ward represented to his audience that "Hindu women sit, with their arms across, lamenting a destiny which will not allow them to go beyond the walls of their houses, until summoned to accompany their master to the funeral pyre". ${ }^{19}$ This "Bengalee"' warned against Christian misperceptions of Hindu religion that might proceed from Ward's unbridled exaggeration and generalization. In other words, he objected to a facile extrapolation from the particular to the universal. It is this sort of extrapolation, I am arguing, on which many Christian perceptions of Hinduism are founded.

Ward's anecdotal delivery encouraged his Christian readers to perceive Hinduism in terms of the episodic. This style encouraged, moreover, the further development of the long-standing Christian tradition of representing Hinduism through visual images. A Christian tradition of visual representation of Hinduism long predates Ward. Sixteenth- and seventeenth-century European images often figured Hindu gods as monsters or devils, assimilating Hindu mythology and iconography to biblical and Western classical models. ${ }^{20}$ Nevertheless, Ward's volumes marked a shift in the thematic occupations of these figurations. Hindoos did not itself include illustrations, but Ward's lively and passionate description of human suffering and deprivation spawned a legacy of Western visual representations of Hinduism whose latest incarnations are Western news media's summary but titillating treatment of such Indian matters as dowry murder and caste. Prior to Ward, drawings and lithographs had featured the art and architecture of Hinduism and illustrated its mythology. With Ward, the Western gaze fixed on the reputed victims of Hindu ideology. Bringing Ward's agonized prose to visual life, woodcuts of women casting themselves on their husbands' funeral pyres, decapitated human heads lying at the threshold of small shrines, and devotees piercing their flesh with hooks soon appeared as regular features of missionary newspapers. ${ }^{21}$ Among the abundant examples of passages lending themselves to lurid illustration I might cite is the following description by Ward of a practice allegedly intended to dismiss the evil spirit tormenting an infant.

The late Mr [John] Thomas, a missionary, once saved and restored to its mother an infant which had fallen out of a basket, at Bholahatu, near Malda, at the moment a shackal [jackal] was running away with it. As this gentleman and $\mathrm{Mr}$ [William] Carey were afterwards passing under the same tree, they found a basket hanging in the branches containing the skeleton of another infant, which had been devoured by ants. ${ }^{22}$

Like this image, Christian traditions of narrative and visual (mis)representation of Hinduism disclose a deep ambiguity in their apprehension of Indian life. Often motivated by concern for human suffering and passion for civil and economic justice - themes distilled from the teachings of Christ evangelical representations like Ward's (and often those of the popular media) pursue an unabashedly voyeuristic strategy, uncovering particular and limited tragedies to suggest the unreformable essence of Hinduism. Rarely supplying the context necessary to appreciate the history and nature of the issue at hand, they provoke a swift emotional response and deter further interrogation.

Ward's Hindoos and the evangelical literature on India it inspired show one of the enduring shortcomings of personal encounter and its narration as means for furthering interreligious understanding. If Ward helped advance the study of Hinduism by directing attention to the daily experiences of marginalized peoples, his work also displays an uncritical reliance on the anecdote as a mode of cross-cultural description. Both the power and the limitations of personal contact as hermeneutic lens 
are open to view in Ward's narration of episodes of daily Indian life in early nineteenth-century Bengal. With its colour and impact, the anecdote obscures the dangers of generalization. Too often, Christian perceptions of Hinduism have taken their lead from those who would display a single, extraordinary episode as the essence of Hinduism. The anecdote becomes emblem and easily substitutes for the disciplined "thick" scrutiny that distinguishes scholarly ethnography and earnest interreligious dialogue. Christian literature about India often displays this preference for the episodic and eschews the responsibility to pursue a matter beyond the particular that anecdote communicates.

Here I return to my original argument that in matters of interreligious understanding, all perception is simultaneously misperception. The anecdote is powerful because it communicates the personal and the particular. In it, human experience meets human experience, and in this meeting there is truth in both the broad and narrow senses. Like a photograph, however, the anecdote feigns an irrefutability because it conveys the concrete. Although very sorely equipped to provide context, articulate qualification, or fix critical distance, it functions as a deterrent to serious inquiry. This tradition of apprehending Hinduism through the anecdote and visual image is a deeply ingrained Christian habit, and one certain source of Christian misperceptions of Hinduism.

\section{Notes}

1. Among his contemporaries, F. J. Shore, son of former governor-general John Shore, said that Ward's "description of the Hindus ... was incorrect and unfair". Notes on Indian Affairs. 2 vols. (London, 1837), vol. 1, p. 518. Abbé Dubois rejected Ward's habit of "representing these people under the blackest and most odious colours", Letters on the State of Christianity in India. (London, 1823; repr. New Delhi: Associated Publishing House, 1977), p. 77. Stephen Neill has noted Ward's concern for factual accuracy while acknowledging many "have deplored the spirit by which he was actuated", A History of Christianity in India, 1707-1858. (Cambridge: Cambridge University Press, 1985), p. 449.

2. 4 vols. (Serampore: Mission Press, 1811).

3. The first printing of the two-volume second edition bears this title, to which all references in this essay refer (Serampore: Mission Press, 1815). Ward varied the title slightly as he produced new editions or reprints of old editions.

4. Quoted in E. Daniel Potts, British Baptist Missionaries in India, 1793-1837, (Cambridge: Cambridge University Press, 1967), p. 22.

5. Sunil Chatterjee, "Reverend William Ward, 1769-1823", Serampore College Students' Magazine (1972), pp. 86-97.

6. David Kopf, British Orientalism and the Bengal Renaissance: The Dynamics of Indian Modernization, 1773-1835, (Berkeley and Los Angeles: University of California Press, 1969), p. 72.

7. Ward, Hindoos, vol. 2, p. Ixxvii.

8. Ward, Hindoos, vol. 1, pp. 313-445. See William Bysshe Stein, ed., Two Brahman Sources of Emerson and Thoreau, (Gainesville, FL: Scholars' Facsimiles and Reprints, 1967), pp. xv-xx, and a reprint of the translation from Ward's 1822 edition, pp. 119-292.

9. See Javed Majeed, Ungoverned Imaginings: James Mills' The History of British India and Orientalism, (Oxford: Clarendon Press, 1992), pp. 126-30.

10. See many examples of his sacrificial understanding of Hindu ritual in Hindoos, vol. 2., pp. 253-346.

11. Hindoos, vol. 2, pp. 5-230.

12. Hindoos, vol. 2, pp. 295-8.

13. Hindoos, vol. 1, p. 216.

14. Hindoos, vol. 1, pp. 177-9.

15. Hindoos, vol. 2, p. lxxiv.

16. Hindoos, vol. 2, p. Ixxii.

17. Nancy Gardner Cassels, "Some Archival Observations on an Evangelical Tract", Indian Archives 30/1 (1981), pp. 47-57.

18. A summary of his ideas may be found in Ward's Farewell Letters to a Few Friends in Britain and America on Returning to Bengal in 1821, (New York: E. Bliss and E. White, 1821), pp. 60-77.

19. Asiatic Journal 11/62 (Feb. 1821), p. 145.

20. See Partha Mitter, Much Maligned Monsters: A History of European Reactions to Indian Art, (Oxford: Clarendon Press, 
1977), esp. pp. 1-31.

21. An example of these newspapers may be found in The First Ten Years' Quarterly Papers of the Church Missionary Society, to which is Affixed a Brief View of the Society, (London: Seeley and Son, 1826). An analysis of these may be found in my unpublished $\mathrm{Ph} . \mathrm{D}$. dissertation "The Firefly and the Moon: Representing and Constructing Religion in the Context of Colonial Bengal", (Emory University, 1998), pp. 50-73.

22. Ward, Hindoos, vol. 2, p. 319. 